\title{
Motivational Tools for Learning Programming in Primary Schools
}

\author{
VOŠTINÁR Patrik
}

\begin{abstract}
Studying pedagogical sciences for Computer Science subject nowadays does not meet with great interest of students in Slovakia. Education of young generation in this area is strongly affected by small number of well qualified teachers as well as lack of high-quality teaching materials resulting to deplorable knowledge of the pupils. The very same situation is also with preparation of future teachers. They have only limited possibilities of direct contact with pupils during their studies, what leads to weak experience of the future teachers and low motivation of the children for Computer Science subject. This contribution gives a positive example of extracurricular educative activity for pupils from lowersecondary schools, where students of Teaching of Computer Science program and Applied Informatics program were involved as lecturers or tutors. In this activity we used various motivational tools for teaching programming and Computer Science as well. The contribution describes our experience with these tools for programming, which we used in our extracurricular activity - so called "Informatics club" and also in the two primary schools and three secondary schools in the region of Banská Bystrica. Motivational devices, which were used are: education board bbc micro:bit with accessories (IoT set, gamepad, micro:bit cars), didactic devices - robots (Airblock, mBot Ranger, Phiro Pro) and board game Scottie Go!.
\end{abstract}

Keywords: learning aid, extracurricular activity, bbc micro:bit, STEM

\section{Introduction}

Almost 40 years have passed since the integration of computers came into education. During this time, the integration of information and communication technology (ICT) has progressively evolved from the using of simple learning programs in the classrooms to teaching management systems [1]. Today's children have very close relation with games and applications on smartphones and other mobile devices [2]. With these devices it is easier to develop pupils' computational thinking. Mobile devices can be also used to control robots. Recently, the issue of educational robotics has been resonating in many countries at all levels of schools. Many researches show positive result of their research on the increasing interest of young people to study technical and natural science at colleges and universities thanks to the pleasant experience of building and programming robots $[3,4]$. It helps to motivate students to learn science and technology, thus enhancing problem solving skills [5]. The jobs with Computer Science are now very popular, unfortunately in almost all around the world are missing specialists for Computer Science. The same situation is also taught in subject Informatics in Slovak Republic. The solution can be motivation students to study Computer Science from the beginning - primary schools.

In this article we are focused on explanation of our computer science extracurricular activity in our department and explanation of various types of motivation devices for computer science teaching.

\section{Computer science extracurricular activity}

In our Department of Computer Science FNS UMB we are organizing second academic year extracurricular activity for pupils from primary schools. Based on our experiences from the previous academic year 2017/2018, which were unambiguously positive, we decided to use in this activity more tasks with educational robots. We have found that pupils are interested in programming, especially when they can catch their results, for example in the case of LEGO

Central-European Journal of New Technologies in Research, Education and Practice

Volume 2, Number 1, 2020. 
robots. In this academic year 2018/2019 we have this activity twice in a week for 1,5 hours. The students of Teaching of Computer Science program and Applied Informatics program were involved as lecturers or tutors in this activity. Each of our student teach 2-3 children from the primary school. The main focus of this activity is to obtain additional teaching experience for our students and in-crease motivation for studying Computer science (programming). This year we have 49 pupils from different primary schools and 27 students from our department.

More information about the Computer Science extracurricular activity are in page http://www.fpv.umb.sk/katedry/katedra-informatiky/kruzky-organizovane-ki-umb-pre-ziakovzs-a-ss/informacie-o-kruzku-zs.html .

\section{European Researchers' Nights}

European Researchers' Night is the festival of science, which is a yearly organized event throughout Europe. Last year (2018) our department attended this event in Europa Shopping Center (ESC) in Banská Bystrica. In our scientific stand we presented our department - scientific research in our department and didactic devices used in our Computer Science extracurricular activity for primary schools. We presented programming mobile applications in App Inventor, programming didactic devices like Airblock, mBot Ranger, Phiro Pro and BBC micro:bit. We had prepared simple programming tasks for each of didactic devices (each task had to be solved in couple of minutes). Example of tasks were to create mobile app with button, which change background color of screen, create simple environment for moving various type of robots. We used the observation method for this activity. The result of observation was that almost all of the pupils (also their teachers) were very excited. Many of them have signed up for our free Computer Science extracurricular activity for primary schools. Figure 1 shows the Airblock and micro:bit programming in ESC.

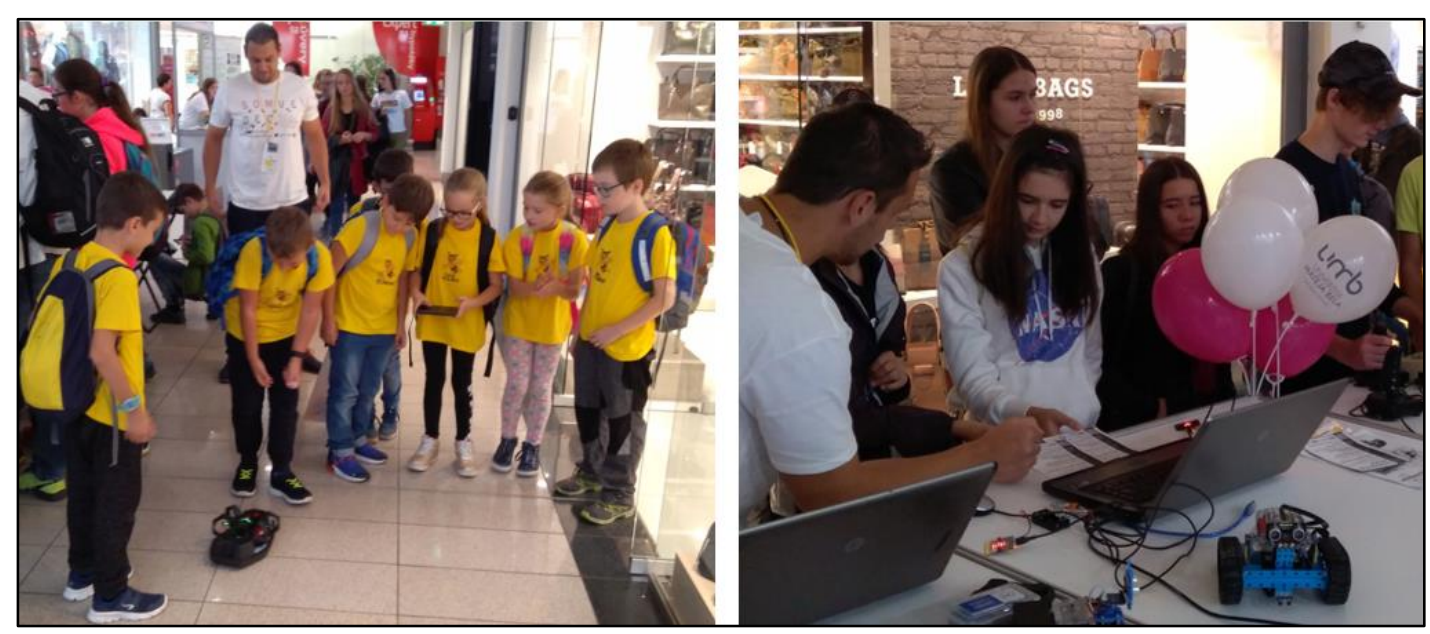

Figure 1: Presenting robots on European Researchers' Nights

\section{BBC micro:bit}

The educational board BBC micro:bit consists of 25 individually programmable LEDs, 2 programmable buttons (A,B), physical connection pins, light and temperature sensors, motion sensors, compass, battery socket, radio and Bluetooth antenna [6]. In the Figure 2 is educational board BBC micro:bit.

Central-European Journal of New Technologies in Research, Education and Practice

Volume 2, Number 1, 2020. 


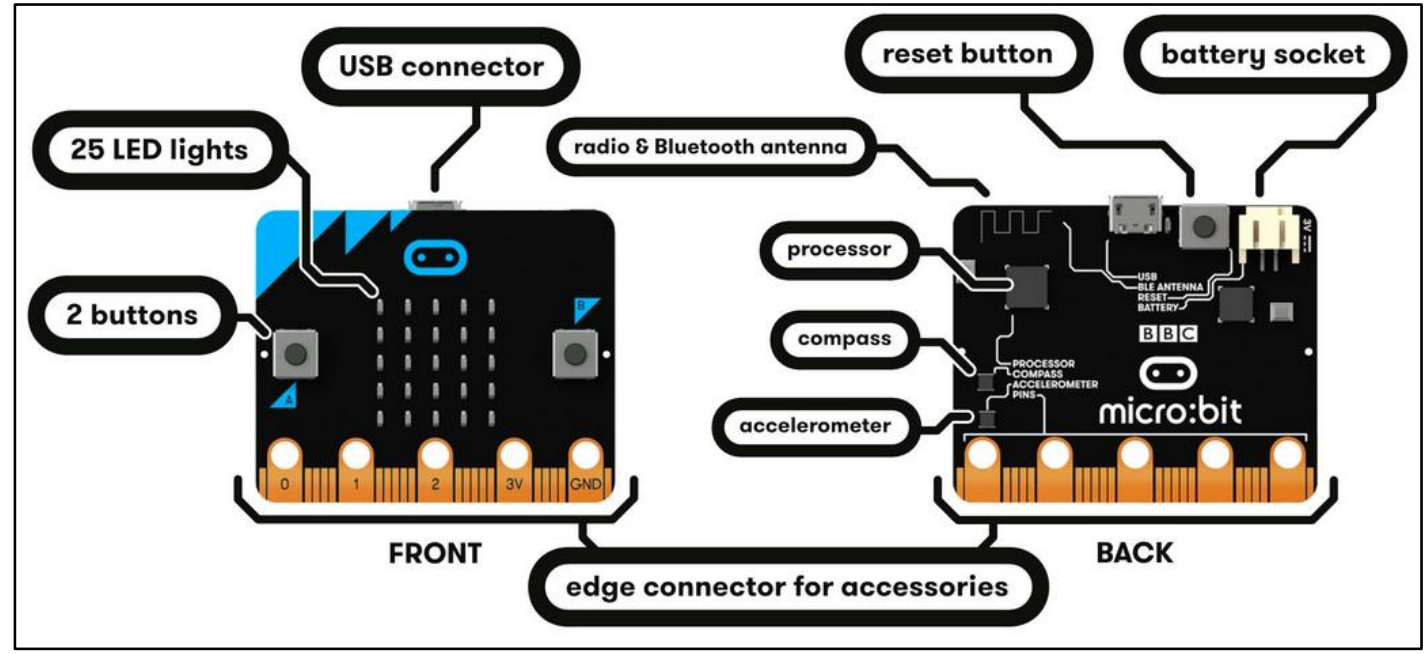

Figure 2: Educational board BBC micro:bit (microbit.org)

Micro:bit is a low-cost device that was assigned to every 11-12 year old in the UK in 2016 [7]. The main microcontroller on the micro:bit is an ARM M0 chip, similar to those found in many mobile devices [8]. Micro:bit has a lot of accessories like gamepad, GPIO Expansion, Sensor Board, 1.8inch colorful dis-play, etc. For programming educational board micro:bit it is possible to use Microsoft MakeCode editor (programming with blocks), JavaScript and MicroPython.

\subsection{Gamepad and Micro:bit cars}

The most interesting accessories for micro:bit are gamepad and micro:bit cars. Which child wouldn't want to develop behavior of their own gamepad to control the car? There are many types of gamepad and micro:bit cars. We chose the cheapest gamepad in our shops and as the car we chose AlphaBot2. For programming gamepad and cars, it is necessary to add extension to Microbit Makecode (according wiki of the device). The task for pupils were at first to program all of the gamepad buttons (7 buttons) and behavior of joy-stick movement. After this task were finished they had to create communication between gamepad and car (radio communication - sending integer or string values on the same frequency). After they received message from gamepad, they had to program movement of the car. Figure 3 shows the gamepad with source code of radio communication. 


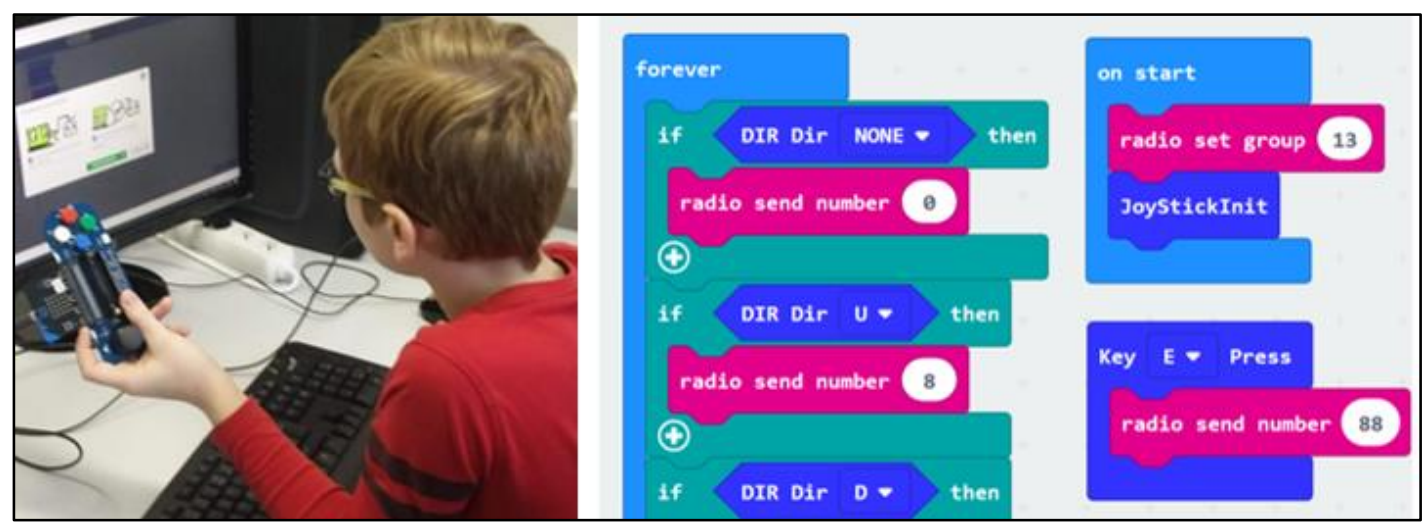

Figure 3: BBC micro:bit with gamepad

\subsection{Io'T extension}

Another important extension for micro:bit is IoT extension. With this extension it is possible to use various types of integrated circuits. This extension can replace microcontroller Arduino. In the Figure 4 there are IoT extensions for micro:bit.

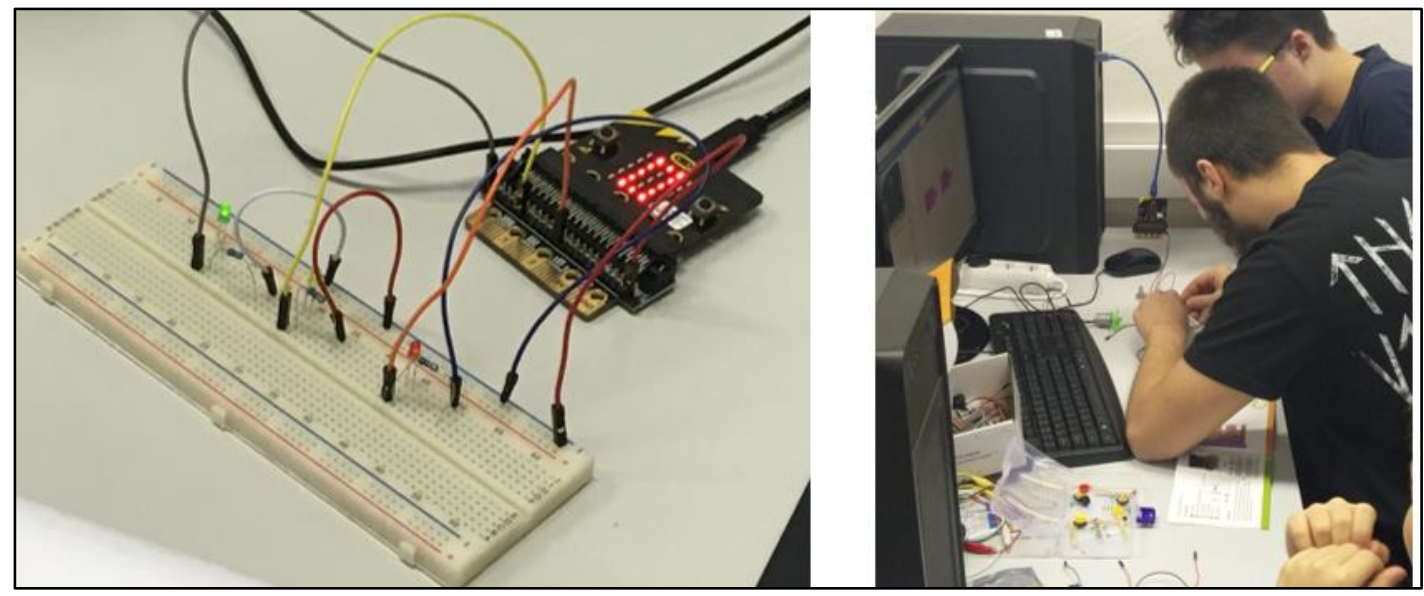

Figure 4: BBC micro:bit with IoT extension

\section{$5 \quad$ Didactic devices - robots}

A physical computing in teaching process can be reached with using programmable robots. It is nothing special, if these devices are found in preschool or primary schools [9]. Nowadays there exist a huge number of programmable robots e.g., LEGO Mindstorms robots, Bee-Bot, ProBot, Sphero robots, Ozobot, robots created by Makeblock (Codeybot, Airblock, mBot), Phiro Pro, etc. Each of these robots have different advantages and disadvantages. The using of robotics in education hasn't very long history, but we can't ignore the fact, that robotics is constantly and rapidly developing and in the future will be robots part of our daily life [10]. We will concentrate on using Airblock, mBot Ranger and Phiro Prot in education. 


\subsection{Airblock drone}

Airblock is the programmable drone, which can be transformed into a flying drone, hovercraft, water hovercraft, spider etc. It is indoor-friendly, because it is made from engineering foam (1 main module - CPU and 6 dynamic magnetic hexagons). For programming Airblock it is possible to use mobile devices with iOS or Android operating system [11]. Programming in this environment is based on block programming like in Scratch. Pupils can create their own environment of the controller (it is possible to choose various predefined commands like buttons, power switch command, gamepad, etc.). Except to basic robot motion and controls blocks (if, while, etc.) it is also possible to use blocks from math, event (shake, tilt tablet, etc.), detect (gyro value, temperature, etc.) and display (LED colors).

\section{Example of task - "Draw air cube with Airblock drone"}

This task is appropriate after completing the tasks of rendering 2D geometric shapes (square, rectangle) with drone. We used this task for independent work in a team or individuals - pupils have to find results on how to draw 3D shape - cube in the air. Pupils have to find appropriate commands based on their previous experience (tasks with drawing 2D shapes). In case that pupils cannot find an answer, the teacher can help with blocks, which can they used. Based on our experience, this task is simple for pupils, because they had experience with drawing $2 \mathrm{D}$ shapes. Figure 5 shows result of this task.

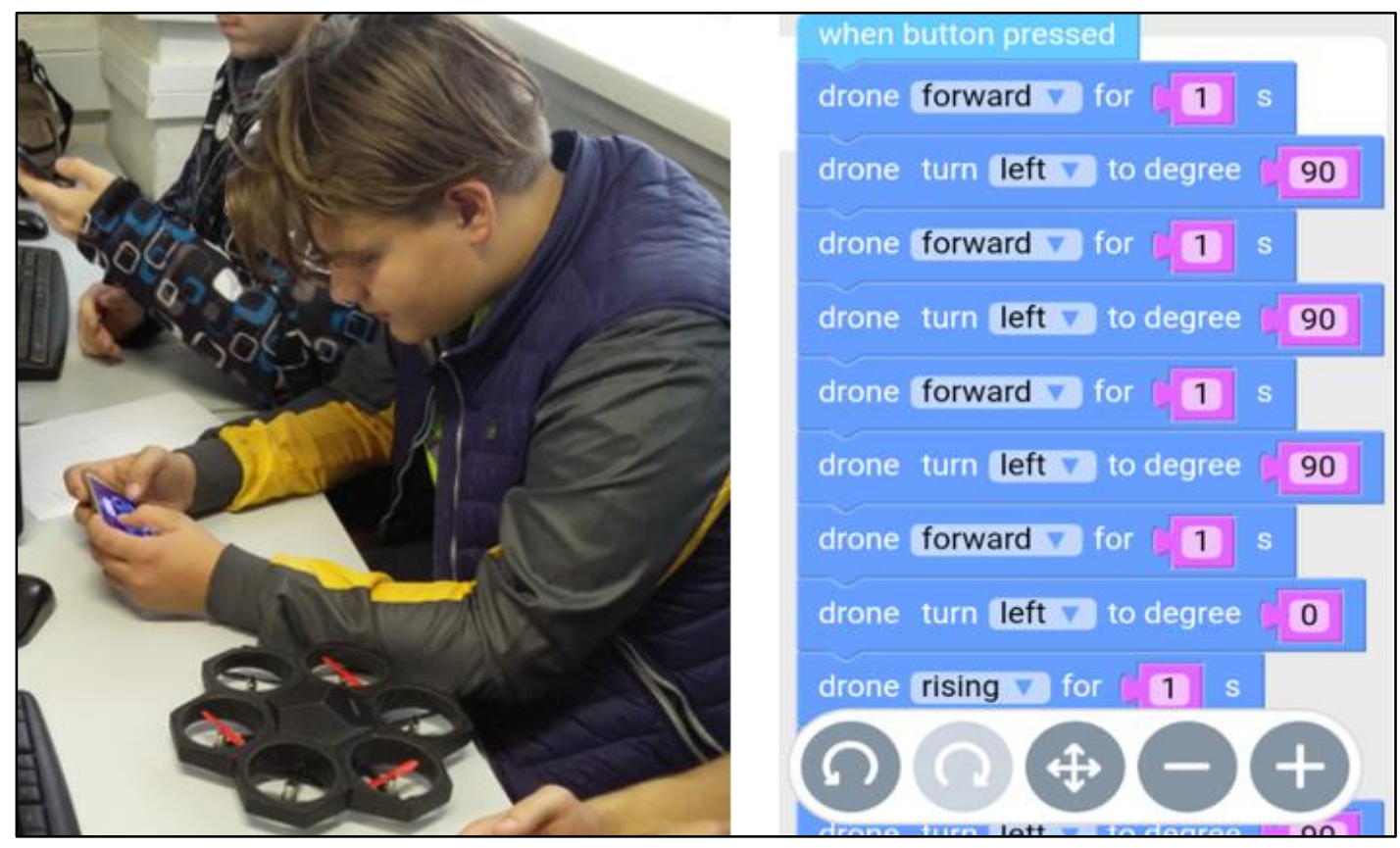

Figure 5: Airblock code for drawing cube [11]

\section{2 mBot Ranger}

Robot mBot Ranger is an advanced version of mBot. It can be transformed into 3 forms (Allterrain Off-road Land Raider, Super Speedy Dashing Raptor, Self-balancing Nervous Bird). This robot is created by Makeblock, the same company as Airblock drone, this mean that for programming you can use the same mobile app like for Airblock (just change the robot version). mBot Ranger contain following sensors: Light sensor, Temperature sensor, Sound sensor,

Central-European Journal of New Technologies in Research, Education and Practice

Volume 2, Number 1, 2020. 
Ultrasonic sensor, Line Follower sensor and Gyroscope. The main-board of this robot is based on microcontroller Arduino, that means it can be programmed also in Arduino IDE environment.

\section{Example of task - "Variables"}

Commands of mBot Ranger consists of various basic programming structures such as variables, procedures, conditions, loops, etc. Figure 6 is $\mathrm{mBot}$ Ranger with a source code of programming task for practicing variables. The task is:

"After the button "Random even-odd" is pressed create a variable, which will be initialized to a random integer from 1 to 10 . If the variable is even, then set ALL LEDs on mBot to color green and run forward at speed 100. If the variable is odd, then set all LEDs to color red and run backward at speed 100."

This task is appropriate for practicing the topic variables (and also the repetition of conditions and mathematical operations - random number, even/odd). The children could solve this task individually or in the team. After testing this task in our extracurricular activity for primary school children we find that this task was easy for children. All of them known how to solve this task.

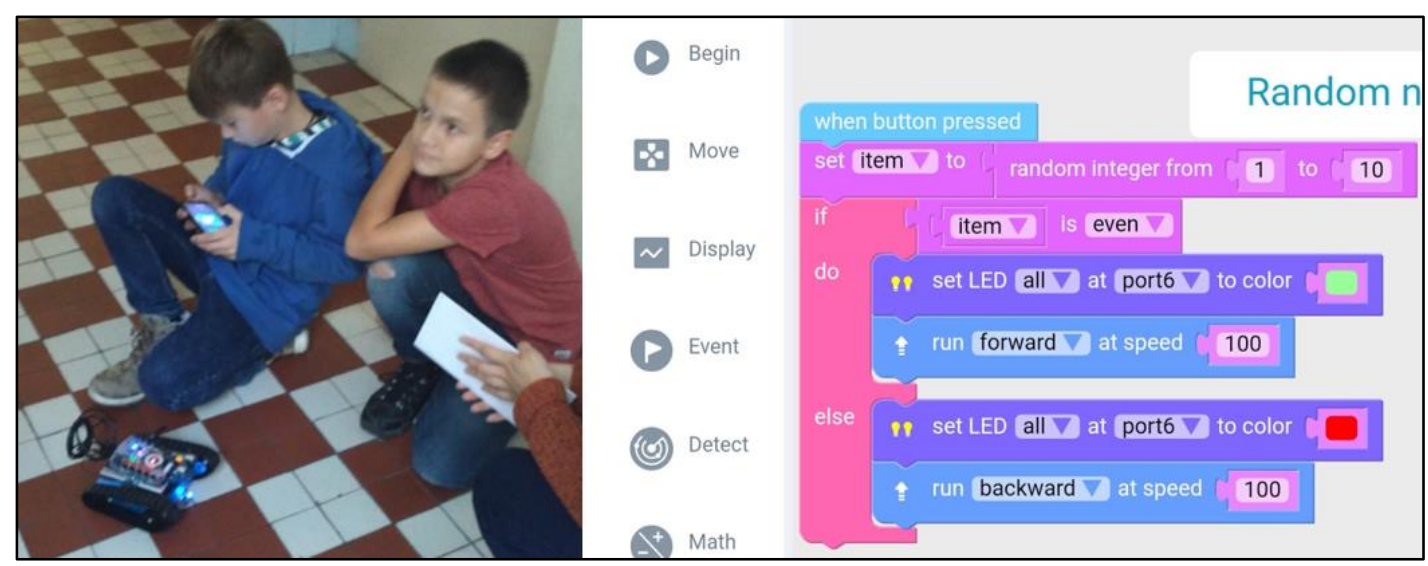

Figure 6: mBot Ranger programming random number

\subsection{Phiro Pro}

Phiro Pro is a LEGO compatible programmable robot designed for young people ages 9 to 18 (recommended). Phiro Pro can be used with programming in computers (Scratch, Snap4Arduino), mobile devices (Pocket Code for iOS and Android), programming by sequential keys (located on the top of the Phiro Pro) and Swish Cards (little cards like credit cards, each card means one command, it is possible to use one or more cards together) [9]. Phiro Pro offers functionality to code basics robot commands such as line follower, edge detection, obstacle avoider, etc. The most interesting tasks for Phiro Pro are with Swish Cards.

\section{Example of task - "Swish Cards - movement"}

"Find appropriate Swish Cards for moving robots to one step forward, one step backward, turn right, turn left, left LED red, right LED red. After that insert cards to Phiro Pro in following orders: After that insert cards to Phiro Pro in following orders: one step forward, turn LED red, turn left, turn LED right, turn right, one step backward. Discuss in the small group why you used cards left LED red, right LED red." 
Phiro Pro and Swish Cards are suitable for introduction to teaching programming. Pupils can learn the gradual execution of orders, basic robotics. In the Figure 7 there are photos of programming Phiro Pro with mobile application Pocket Code and Swish Cards.

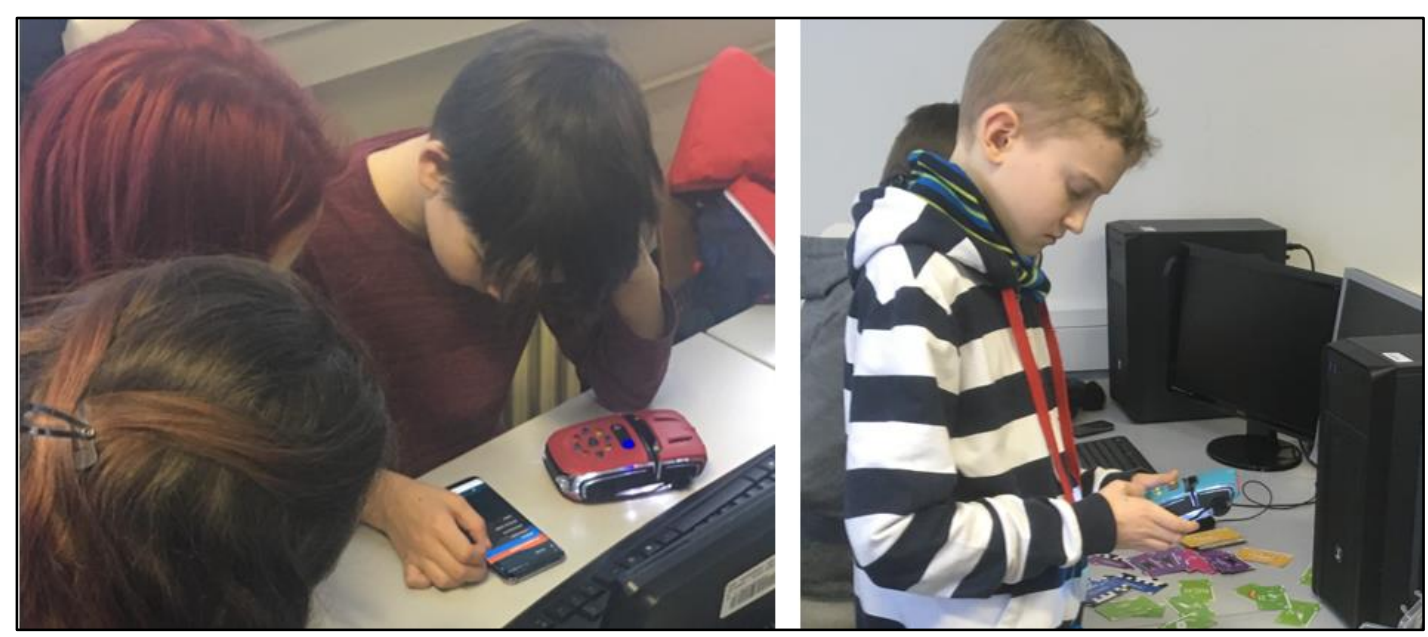

Figure 7: Phiro Pro programming with Pocket Code and Swish Cards

\section{Programming board game Scottie Go!}

Scottie Go! is education game to teaching programming. It consists of 179 blocks of code, which have to be used to solve 91 tasks. The blocks of the code have to be joined together like puzzle. The tasks are in special mobile app (iOS, Android and Windows app). Pupils must solve tasks in board game, then to use camera of mobile device and scan their results. The app evaluates the pupil's solution with 1-3 stars (each task has multiple solutions). In the Figure 8 there are photos of programming Scottie Go!

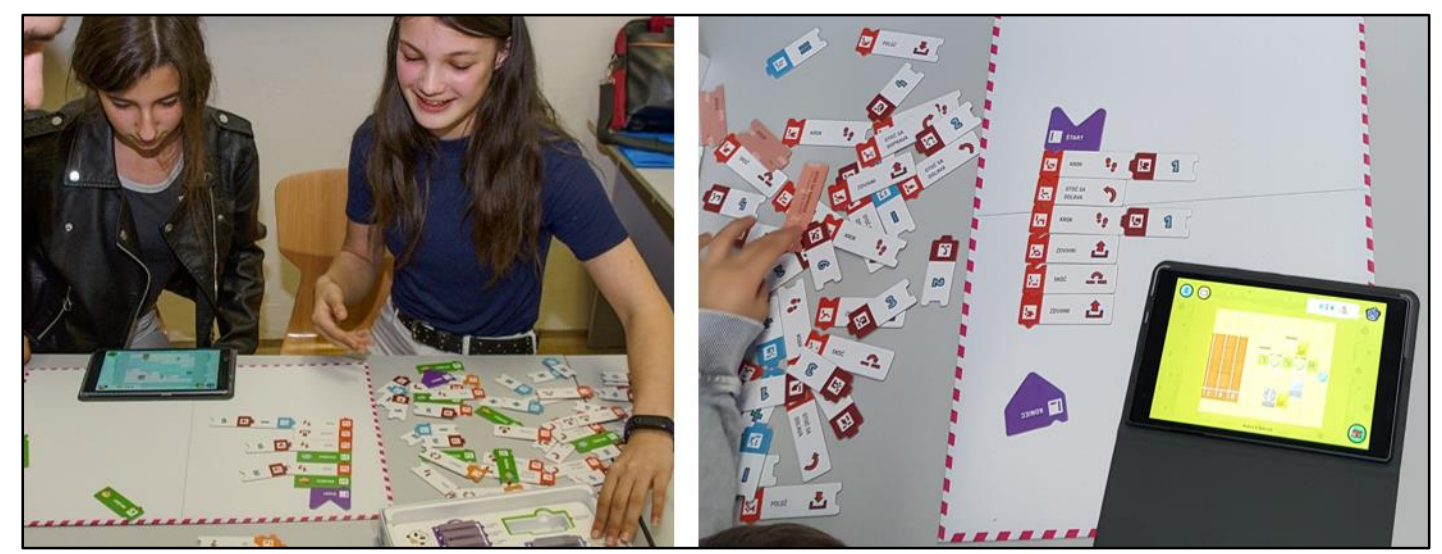

Figure 8: Scottie GO! programming

The disadvantage of this board game is that there is no possibility to create own examples, only

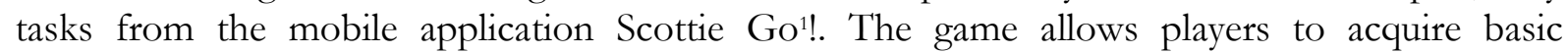
programming concepts such as loops, conditionals, variables or functions. It can be used as a basic

${ }^{1}$ https://play.google.com/store/apps/details?id=com.netictech.scottiego\&hl=sk

Central-European Journal of New Technologies in Research, Education and Practice

Volume 2, Number 1, 2020. 
tool to introduce and teaching programming. The main advantage of this game is, that it allows children to work in teams without teacher help. The mobile app describes each block, which should be used in a game.

\section{$7 \quad$ Methodology and research}

All of the didactic devices mentioned in chapter 3 and 4 are used in our Computer Science extracurricular activity for primary schools in the Department of Computer Science FNS UMB (49 pupils between 10-15 years old). We also tested using these devices in the teaching process during 2018/2019 in primary school Dominika Savia in Zvolen (14 pupils, 14-15 years old). As a method of measuring data, we used observation and questionnaires. In the questionnaire we focused on measuring motivation of using didactic robots (through observation and questionnaires). We asked 44 pupils (13 pupils from primary school and 31 pupils from extracurricular activity) from 63 pupils. The reason of smaller number of responders was that not all of the pupils visited each week our extracurricular activity, so we decided to collect answers only from pupils which completed all lessons. Questionnaires consist of 12 questions, where we asked gender, age, experience with programming. The important questions were regarding using micro:bit. Figure 9 shows diagram most important questions for our small research.

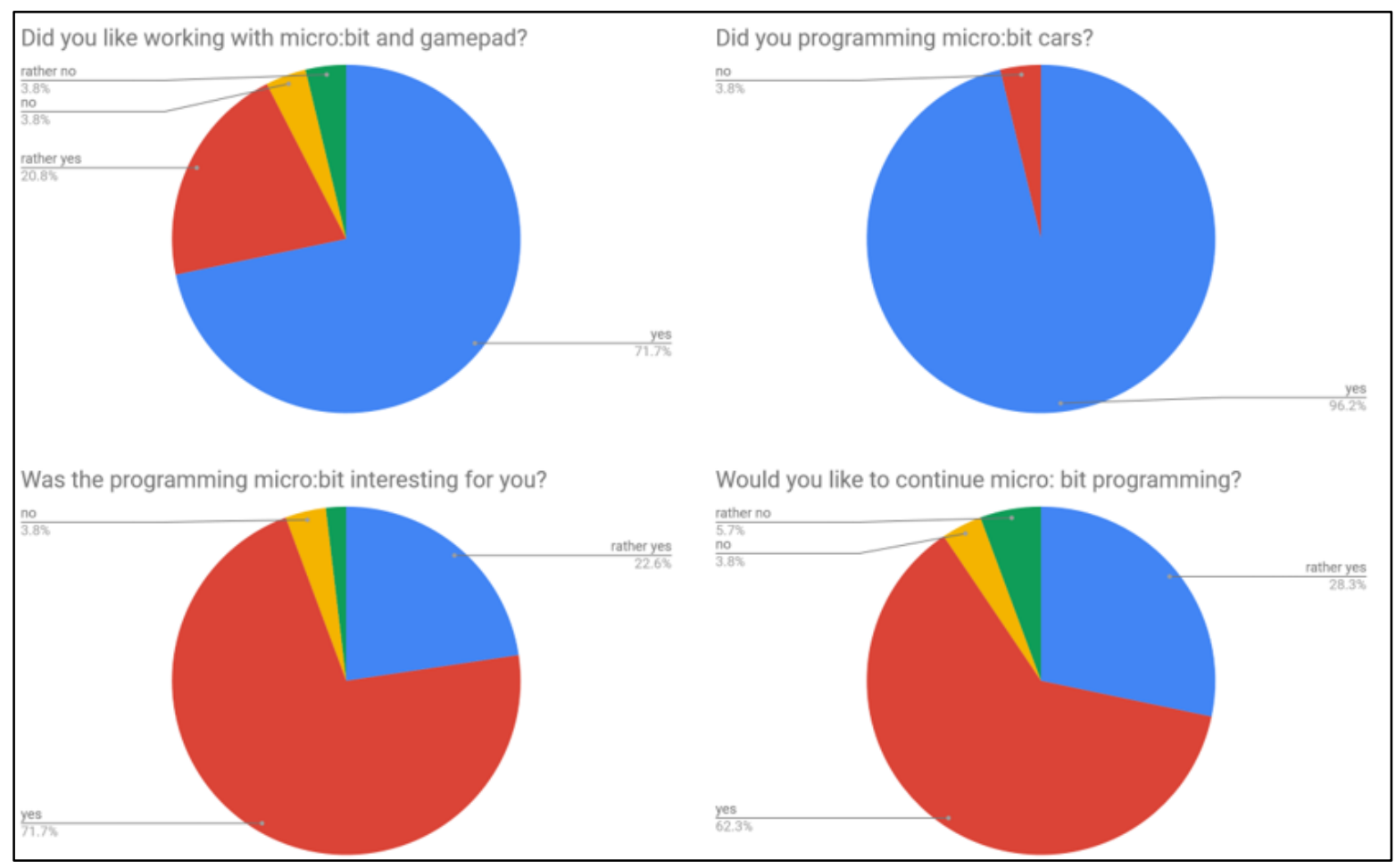

Figure 9: Questionnaires results

Answers form the question "Did you like working with micro:bit and gamepad?" showed that $71,7 \%$ students like programming educational board BBC micro:bit with gamepad. 20,8\% of the students said rather yes. Only 7,6\% answers wrote that they does not like programming micro:bit and gamepad.

Central-European Journal of New Technologies in Research, Education and Practice

Volume 2, Number 1, 2020. 
Question "Did you programming micro:bit cars?" showed that almost all of them $(96,2 \%)$ like programming micro:bit cars.

For $71,70 \%$ students were the programming micro:bit interesting, according the question "Was the programming micro:bit interesting for you?" $22,60 \%$ students wrote that rather yes, then no.

The graph from the question "Would you like to continue micro:bit programming?" showed that $62,30 \%$ want to continue with programming BBC micro:bit and $28,30 \%$ wrote rather yes, than no. Only few of the students does not want to continue with programming micro:bit.

Other question from the questionnaire were focused on "What I did not like with working with micro:bit". Almost all of them wrote that "everything was great".

\section{Conclusion}

In this article we are focused on motivation of the children for Computer Science subject. We described motivation devices - programmable robots which we used in our extracurricular activity for pupils from lower-secondary schools, where students of Teaching of Computer Science program and Applied Informatics program were involved as lecturers or tutors. We described devices which we most used - education board micro:bit with accessories, didactic devices - robots and board game Scottie Go! Described devices are good for motivating to studying Computer Science, but from our experience it is better when the pupils have experience with programming from Scratch before then they started using these devices.

We did small research, where we used modern educational aids, which are currently used in teaching Computer Science in the world. In our research we used observation and questionnaires. We plan to continue with our research if using these educational aids will increase interest of about studying Computer Science. The observation and the questionnaire show that usingt these educational aids incresed students interest about stydying Computer Science.

This contribution has been processed as part of the grant project Interactive Applications for Teaching Mathematics at Primary Schools, project no. 003TTU-4/2018.

\section{Bibliography ${ }^{2}$}

1. M. Pokorný: Kurz desatinné čísla. In Sborník př́spěvků z konference a soutěže eLearning 2018. Hradec Králové : Gaudeamus, 2018, s. 15-19

2. N. Klimová, D. Horváthová: Sút’až KODU CUP ako podporný prostriedok algoritmického myslenia. In DidInfo\&DidactIG 2017. Banská Bystrica: Univerzita Mateja Bela, Fakulta prírodných vied, 2017, s. 197-198

3. M. Havelka, V. Stoffová: Robotika - Stavba a programování robotů (LEGO Mindstorms NXT a EV3) 1. vyd. Olomouc : Pedgogická fakulta UP v Olomouci, 2017. 85. s.

4. V. Stoffová, O. Takáč: Robotické stavebnice v príprave učitel’ov informačnej výchovy (Robot kits in teachers preparation for information education). In Havelka, M.,

\footnotetext{
${ }^{2}$ The data as indicated in the source are to be followed. The main principle is to make the source reachable.
}

Central-European Journal of New Technologies in Research, Education and Practice

Volume 2, Number 1, 2020. 
Chráska, M., Klement, M., Serafín, Č. (ed.): Trendy ve vzdělávání 2013. Olomouc : agentura GEVAK s.r.o., 2013. 315-322. s. ISBN 978-80-86768-52-6 / ISSN 1805-8949

5. N. Klimová, D. Horváthová: Robot Phiro ožíva v rukách detí. In DIDINFO 2018, s. $270-277$

6. P. Voštinár, N. Klimová, J. Škrinárová: Before we start Arduino. In INTED2019 proceedings : 13th international technology, education and development conference. Valencia : IATED Academy, 2019, pp. 7218-7223

7. S. Sentence, J. Waite, L. Yeomans, E. Maclead: Teaching with physical computing devices: the BBC micro:bit iniative. In Proceedings of the 12th Workshop on Primary and Secondary Computing Education (WiPSCE '17). ACM: New York, 2017, pp. 87-96

8. M. Cápay, N. Klimová: Engage Your Students via Physical Computing!. In IEEE Global Engineering Educatin Conference (EDUCON), 2019, pp. 1250 - 1257

9. V. Stoffová, M. Zboran.: Hravá forma stavby a programovania robotov na základnej škole. In: Trendy ve vzdělávání, 11, 2018, č. 2, s. 130 - 139. ISSN 1805-8949

10. V. Stoffová, M. Havelka.: Práca s robotickými stavebnicami na 2. stupni ZŠ - Zbierka riešených úloh. 1. vyd. Olomouc : Pedgogická fakulta UP v Olomouci, 2018. 66.

11. P. Voštinár, N. Klimová, D. Horváthová: The programmable drone for STEM education. In Entertainment computing - ICEC 2018 : international conference on entertainment computing (IFIP-ICEC'18). Cham : Springer Nature Switzerland, 2018, pp. $205-210$

\section{Authors}

\section{VOŠTINÁR Patrik}

Matej Bel University, Faculty of Natural Sciences, Department of Computer Science, Banská Bystrica, Slovakia, e-mail: patrik.vostinar@umb.sk
About this document

Published in:

CENTRAL-EUROPEAN JOURNAL OF NEW TECHNOLOGIES IN RESEARCH, EDUCATION AND PRACTICE

Volume 2, Number 1. 2020.

ISSN: 2676-9425 (online)

DOI:

10.36427/CEJNTREP.2.1.420

\section{License}

Copyright (C) VOŠTINÁR Patrik. 2020.

Licensee CENTRAL-EUROPEAN JOURNAL OF NEW TECHNOLOGIES IN RESEARCH, EDUCATION AND PRACTICE, Hungary. This article is an open access article distributed under the terms and conditions of the Creative Commons Attribution (CC-BY) license.

http://creativecommons.org/licenses/by/4.0/

Central-European Journal of New Technologies in Research, Education and Practice

Volume 2, Number 1, 2020. 